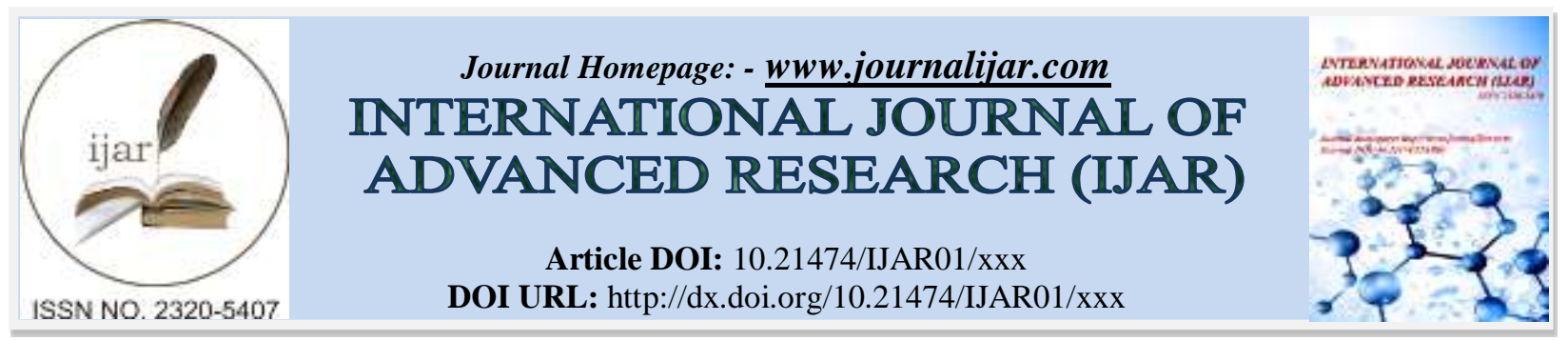

RESEARCH ARTICLE

\title{
KHARSUTRA THERAPY - A MINIMAL INVASIVE PARASURGICAL TECHNIQUE FOR THE TREATMENT OF PATIENT WITH FISTULA IN ANO - A SINGLE CASE STUDY.
}

\author{
Jyoti N. Shinde.
}

Associate Professor, Dept. Of Shalya Tantra' Shri Ayurved College, Nagpur 440009.

\section{Manuscript Info}

Manuscript History

Received: $x x x x x x x x x x x x x x x$

Final Accepted: $x x x x x x x x x x x x$

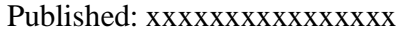

Key words:-

Bhagandara, Ksharsutra, Fistula-in-ano, Apamarga Kshar,Snuhi Latex.

\begin{abstract}
Bhagandara (Fistula- in- ano), one of the Ashta Mahagada stated in Sushrut Samhita is mostly a chronic and complicated disease with higher recurrency rate. Ksharsutra is one of the special form of treatment modality stated in the treatment of Nadi Vrana by Acharya Sushruta. Ksharsutra is a medicated thread coated with herbal drugs and rendered alkaline. Ksharsutra therapy is proved to be a most successful and preferred treatment modality for the patient with Fistula- in- ano with negligent recurrency rate.Patients who are not willing for surgery or who are old age, or having another disease or unfit for surgery can be opted for the Ksharsutra therapy.In the present single case study, a patient with chronic, complicated Fistula-in-ano , who was operated twice for the same and facing recurrence within a year was treated successfully with Ksharsutra therapy where the complete excision of Fistula track was achieved within 14 weeks with no recurrency till now.
\end{abstract}

Copy Right, IJAR, 2017,. All rights reserved.

\section{Introduction:-}

The management of Fistula in ano in an effective manner has always been a challenge to the surgeons all over. In Ayurveda, field of Proctology (Ano-rectal Disorders) is one such area which still has a lot of scope for research through Ayurvedic approach. Ayurveda certainly has immense potential to overcome the challenging unsolved problems of various ano -rectal diseases. Ksharsutra Therapy is one of the most successful and preferred treatment available for the patients of Fistula-in-Ano from ancient time to present era in India with thousands of patients having success. It is a unique treatment of Ayurveda gaining popularity globally.

In the present single case study, attention is paid on BHAGANDARA. According to Sushrut Samhita, Bhagandara starts as a perianal PIDAKA which suppurates and on opening leads to Bhagandara ie. Fistula-in-Ano. According to modern medical sciences, Fistula-in-Ano is a chronic abnormal communication, usually lined to some degree by granulation tissue which connects deeply in the anal canal or rectum and superficially on the skin around the anus. It usually results from an ano-rectal abscess which burst spontaneously or was opened inadequately.

Ksharsutra is a herbal medicated thread .Ksharsutra is a Sanskrut phrase in which Kshar refers to anything that is corrosive or caustic, while sutra means a thread. Ksharsutra is coated with herbal drugs and rendered alkaline.

Corresponding Author:- Jyoti N. Shinde.

Address:- Associate Professor, Dept. Of Shalya Tantra' Shri Ayurved College, Nagpur 440009. 
Introduction of Ksharsutra into fistulous track gradually and slowly curette the pyogenic membrane and fibrous tissue, drains the pus, clean the tract and enhance the healing by forming healthy granulation. Thus it decreases symptoms like pain, burning sensation and inflammation in Fistula-in-ano.

The purpose of the study is to highlight the effect of Ksharsutra in the patient with recurrent fistula who was operated twice for the same. In the present study, efforts are made to evaluate the efficacy of unique procedure in the management of Fistula-in-ano.

\section{Material and method:-}

In the preparation of Ksharsutra (medicated ceton), following three herbal drugs are used.

1. Apamarga Kshar (Alkaline powder of Achyranthus aspera (Family-Amaranthaceae)

2. Suhi Latex (Latex of Euphorbia nerifolia. (Family-Burseraceae).

3. Powder of Termeric ( Curcuma longa),(Family-Ascitaminacea).

\section{Preparation of Ksharsutra:-}

As per standard protocol for the preparation of Ksharsutra, surgical linen thread -Barbour no. 20 with tensile strength $5 \mathrm{~kg}$ was manually coated 11 times with the latex of Snuhi, followed by 7 coatings of Snuhi latex \& alkaline powder of Apamarga Kshar alternatively and dried .In the final phase ,3 coatings of Snuhi latex \& Turmeric powder was given alternatively. The thread thus prepared was sterilized by ultraviolet radiations and placed in airtight glass tubes. The PH of the thread was ensured to be about 9.75 , while the length was about 11 to $14 \mathrm{~cm}$.

\section{Patient Details:-}

A 25 years old male patient, Hindu by religion named Vishal Sharma, resident of Nagpur, telecom operator by occupation received in the Shalya OPD of Shri Ayurved College,Nagpur on dated 21.022017.

\section{Chief Complaint:-}

The patient was presented with the history of recurrent discharging boils in peri-anal region with local itching, pain and discomfort, pus discharge, sometimes mixed with blood through boil since 8 months.

- Associated Complaints :

Painful defecation, soiling of clothes and local itching

- Previous Medical History :

No medical history of Diabetes Mellitus, Hypertension ,Koch’s, Bronchial Asthma and Drug allergy.

- Previous Surgical History :

1 History of Perianal Abscess since 1 year

2 Fistula-in-ano since 8 months

- History of Ano-Rectal Surgeries :

1. Ischio-rectal Abscess, Incised and Drained at Dr Desai's Nursing Home, Khamla on dated 18.01.2016.

2. Total Fistulectomy at Govt. Medical College and Hospital, Nagpur on dated 28.07.2016

\section{- On Examination :}

General Condition Moderate, Afebrile, Pallor, No edema, No ecterus, Temp. 97.6 F ,Pulse 78/min. regular, Respiration 22/min. BP 110/80mm of $\mathrm{Hg}$, weight $61 \mathrm{Kg}, \mathrm{R} \mathrm{S}$-Chest clear, CVS- NAD, ECG normal, CNSConscious, well oriented, GIT : P/A Abdomen soft, non-tender, bowel sound present

- Per Rectal Examination: Two External openings of Fistula-in-ano situated at 1 o'clock \& 11 o'clock respectively in perianal region with indurated edges, thick purulent discharge mixed with blood, Local tenderness +++

- Laboratory Investigations :

TLC $-14,500 / \mathrm{cu} \mathrm{mm}$

DLC - Polymorphs - $66 \%$, Lymphocytes - $31 \%$ Eosiophils - $2 \%$ Monocytes $-1 \%$ Basophils - $0 \%$

Haemoglobin - 12.5 gm \%

ESR - 46 mm,

Mantoux Test - Negative,

HIV- Non Reactive, 
HB'sAg - Negative,

Fistulogram -Two separate fistula tracks with external openings at 1 o' clock and 11 o' clock respectively in peri-anal region, both tracks join together deep at inter-sphincteric space and commonly opens as a single internal opening in anal canal at midline anteriorly.

- Findings noted on the first day :

No. of external openings -2 , Clockwise position of external openings -1 o'clock and 11 o'clock respectively, Type of Fistula - Trans-sphincteric ,Length of Fistula at 1 o'clock is $8 \mathrm{~cm}$ and 11 o'clock is 6 $\mathrm{cm}$,

Discharge : Thick purulent discharge associated with blood, External Opening : Indurated, presence of fibrous tissue around the opening, Local 1 tenderness +++

\section{Application of Ksharsutra:-}

Before application of Ksharsutra, patient was advised to maintain proper local and general hygiene. Patient was advised to take standard mild laxative Ayurvedic drugs for regularisation of bowel during the whole treatment.

Under all aseptic precautions \& under Spinal Anaesthesia, with patient in Lithotomy position, probing was done through external fistula openings situated at 1 o'clock and 11 o'clock respectively, traced out the tracks by gradually extended to the internal openings. Before taking it out from internal opening, Ksharsutra was threaded into the eye of the probe, and then probe was taken out through anal orifice. Thus ksharsutras were allowed to pass through the fistulous tracks and both ends of Ksharsutra were knotted outside the anal orifice forming a loop, and left it in situ for a week. Thus the primary threading was done in both the fistula tracts. Every time the old Ksharsutras were replaced by newer one after the time interval of seven days, till the healing of the entire tracks. After replacement of ksharsutras, patient was advised to continue his routine work.

Observations:-

Changes observed on the basis of various parameters are mentioned bellow :

\begin{tabular}{|l|l|l|l|l|l|l|l|}
\hline $\begin{array}{l}\text { Sr. } \\
\text { No. }\end{array}$ & $\begin{array}{l}\text { Date of } \\
\text { change of } \\
\text { Ksharsutra }\end{array}$ & $\begin{array}{l}\text { Length of } \\
\text { Track no. 1 }\end{array}$ & $\begin{array}{l}\text { Length of } \\
\text { Track no. }\end{array}$ & Discharge & Pain & Tenderness & Itching \\
\hline 1 & $27 / 2 / 17$ & $8 \mathrm{~cm}$ & $6 \mathrm{~cm}$ & +++ & +++ & +++ & ++ \\
\hline 2 & $2 / 3 / 17$ & $7.6 \mathrm{~cm}$ & $5.5 \mathrm{~cm}$ & +++ & +++ & +++ & ++ \\
\hline 3 & $7 / 3 / 17$ & $7 \mathrm{~cm}$ & $5 \mathrm{~cm}$ & ++ & +++ & +++ & ++ \\
\hline 4 & $15 / 3 / 17$ & $6.4 \mathrm{~cm}$ & $4.4 \mathrm{~cm}$ & ++ & +++ & ++ & ++ \\
\hline 5 & $23 / 3 / 17$ & $5.9 \mathrm{~cm}$ & $3.9 \mathrm{~cm}$ & ++ & ++ & ++ & + \\
\hline 6 & $27 / 3 / 17$ & $5.3 \mathrm{~cm}$ & $3.3 \mathrm{~cm}$ & + & ++ & ++ & + \\
\hline 7 & $3 / 4 / 17$ & $4.5 \mathrm{~cm}$ & $2.5 \mathrm{~cm}$ & + & + & + & + \\
\hline 8 & $23 / 4 / 17$ & $4 \mathrm{~cm}$ & $2 \mathrm{~cm}$ & + & + & + & + \\
\hline 29 & $10 / 5 / 17$ & $3.4 \mathrm{~cm}$ & $1.4 \mathrm{~cm}$ & + & + & + & + \\
\hline 10 & $23 / 5 / 17$ & $2.7 \mathrm{~cm}$ & $0.8 \mathrm{~cm}$ & + & + & + & Absent \\
\hline 11 & $31 / 5 / 17$ & $2 \mathrm{~cm}$ & $0.2 \mathrm{~cm}$ & + & + & Absent & Absent \\
\hline 12 & $7 / 6 / 17$ & $1.1 \mathrm{~cm}$ & $0 \mathrm{~cm}$ & Absent & Absent & Absent & Absent \\
\hline 13 & $16 / 6 / 17$ & $0.6 \mathrm{~cm}$ & Healed & Absent & Absent & Absent & Absent \\
\hline 14 & $23 / 6 / 17$ & $0 \mathrm{~cm}$ & Healed & Absent & Absent & Absent & Absent \\
\hline 15 & $30 / 6 / 17$ & Healed & Healed & Absent & Absent & Absent & Absent \\
\hline 16 & $8 / 7 / 17$ & Healed & Healed & Absent & Absent & Absent & Absent \\
\hline 17 & $25 / 7 / 17$ & Healed & Healed & Absent & Absent & Absent & Absent \\
\hline
\end{tabular}

\section{Results:-}

The time period taken for the complete excision of Fistula tracks by Ksharsutra therapy was approximately 14 weeks or 98 days.

\section{Discussion:-}

The management $f$ Fistula in ano in an effective manner is still a challenge to the medical sciences irrespective of any pathy. 
The modern surgical treatments like Fistulotomy or Fistulectomy often leads to recurrency.

Ksharsutra Therapy for Fistula in ano, mentioned in Ayurveda, is evaluated in the present case study and found to be a most preferable modality of treatment with minimal invasive technique because of the following reasons :

$>$ It is technically easy, safe and simple method and does not require any special paraphernalia. It can be carried out in Out Patient Department, as most of the cases don't require any anaesthesia also.

$>$ It is considered as a cost effective treatment as compared to others.

$>$ As doesn't require hospitalization, patient can resume his normal routine work. Thus patient's social, psychological and economic status is not disturbed during the treatment.

$>$ Impaired continence is transient and related to the stage of 'cutting through' the anal sphincter by Ksharsutra, which subsequently lead to complete recovery, during follow up.

$>$ The rate of recurrence after the treatment is negligible as compared to various other surgical managements.

$>$ It is an ideal management for the old age patients, or having another disease or otherwise unfit for surgery.

$>$ No systemic side effects are noticed with Ksharsutra therapy, although transient infection, local burning sensation, mild pain, itching and slight indurations are observed, which rarely needs medications.

$>$ Post operative tissue damage and scarring are minimal. Thus Ksharsutra therapy is an unique method of drug delivery, most appropriate for healing the track.

\section{References:-}

1. Sushrut Samhita with Commentary of Dalhana,Yadavji Trikamji Acharya,Chaukhamba Surabharti Prakashan, Varanasi,Sutra Sthana 33/4

2. Sushrut Samhita with Commentary of Dalhana,Yadavji Trikamji Acharya, Chaukhamba Surabharti Prakashan, Varanasi, Chikitsa Sthana 17/29-33

3. Bailey \& Loves Short Practise of Surgery, $25^{\text {th }}$ edition, Chapter $69^{\text {th }}$

4. Pankaj Shrivastava \& Manoranjan Shahu, Efficacy of Ksharsutra (medicated ceton) therapy in the management of Fistula-in ano, http//services.bepress.com/wjcs/volz/iss1/art6

5. http://www.ksharsutratherapy.com/all-about-kshar-sutra-therapy

6. S K Sharma,K R Sharma\& Kulwant Sing, Ksharsutra therapy in Fistula-in-ano and other Ano-rectal Disorders, R A V Publication,New Delhi-110026, $5^{\text {th }}$ chapter.

7. Satender Tanwar and Shailaja S V,Ksharsutra boon for cardiac patients with Fistula-in Ano,International Journal of Bioassays,2015,4(03),3766-3769. 